\title{
Value Chains of Carrot Commodity on Suthomadansih Agropolitan Area in Karanganyar Regency
}

\author{
Dwi Feri Yatnanto ${ }^{1}$ \\ PT. Duta Citra Design Consult, Semarang
}

\section{Indah Susilowati}

Program Studi Magister Pembangunan Wilayah dan Kota Universitas Diponegoro, Semarang

Artikel Masuk : 26 Februari 2015

Artikel Diterima : 4 Mei 2015

\begin{abstract}
In 2007, the Central Java Province Government started the implementation of agropolitan program in some regencies with agriculture sector potentialities. The program promoted Suthomadansih Agropolitan Area establishment in Karanganyar Regency. One of the leading commodities from Suthomadansih was carrot. Carrot was considered in the program through infrastructure provision and community development programs. The objectives of the research are to investigate the value chain of carrot commodity in Suthomadansih, and to analyze how the implementation of the agropolitan program is likely to support its value chain. In doing so, there are three indicators that will be identified: the development of supporting infrastructure, agribusiness system, and human resource (Iqbal \& Iwan, 2009). Both qualitative and quantitative analyses applied in the study with the performance table of the implementation of the agropolitan program and value chain analysis as the analytical tool. Referred to the value chain analysis of carrot commodity in Suthomadansih, some agropolitan-related development programs from the local government were conducted from the upstream to downstream flows of carrot commodity. However, some programs failed to support the value chain of carrot so that its improvement could not be optimized including Agribusiness Sub Terminal, Worta Cluster, Vitmaka, and Farm Road Improvement Program. The implementation of the agropolitan program was not sustainable because of the absence of the local government budget support. The program was only implemented for three years (2007-2009) so that there were no significant effects of the program on the agricultural sector, especially for carrot commodity.
\end{abstract}

Keywords: carrot, agropolitan, Suthomadansih, value chain

\section{Introduction}

In 2007, Central Java Government has been starting the implementation of the agropolitan program in some regency that has that has the potential in the agriculture sector, Karanganyar Regency is one of them. Through this program, Suthomadansih was established in Karanganyar Regency. The leading commodity of agriculture from Suthomadansih is vegetable and fruit. It is possible due to the location of Suthomadansih

\footnotetext{
${ }^{1}$ Korespondensi Penulis: PT. Duta Citra Design Consultant, Semarang

Email: dwiferiyatnanto@gmail.com
} 
on the slopes of Lawu Mountain. One of the leading commodities from Suthomadansih is carrot commodity. Carrot commodity is then taken into consideration in the implementation of the agropolitan program, in form of provision of infrastructure and community development programs.

The implementation of the agropolitan program in Karanganyar was originally initiated from farmer groups as named Taman Sari in Tawangmangu District at 2006. The action is then followed up by Kimpraswil (Settlement and Regional Infrastructure Board) of Central Java Province by establishing agribusiness sub terminal in Tawangmangu District, and establishing of agribusiness sub terminal in Karangpandan District, Ngargoyoso District, and Jenawi District in the following year. Development budget of the agropolitan program comes from both of Government of Central Java Province and Local Government of Karanganyar Regency. The implementation of the agropolitan program is conducted over three years (2007-2009) because the Government of Central Java Province no longer provides funding in 2010. Meanwhile, the Local Government of Karanganyar Regency also uses the budget for other agricultural programs. However, the following programs from Department of Agriculture of Karanganyar Regency still support the agropolitan program.

There are several previous researchers focusing on agriculture development in Karanganyar Regency, especially for carrot commodity. But, there is no available research focuses on carrot value chain. A research study of carrot value chain will show the cultivating process of carrot commodity in every step from on-farm (upstream) to off-farm (downstream). As well as to explain how the carrot as the leading commodity gives contribution in the development process of Suthomadansih Agropolitan Area. In addition, the research study is expected to analyze how the implementation of the agropolitan program supports the value chain of carrot as leading commodity in Suthomadansih Agropolitan Area. Thus, the problem will be discussed in this study is "How the value chain of carrot in Suthomadansih is and what the contribution of the agropolitan program in supporting the value chain of carrot as leading commodity in the development process of Suthomadansih are."

\section{Research Method}

In order to conduct the research entitled "Value Chain of Carrot Commodity in Suthomadansih Agropolitan Area in Karanganyar Regency," quantitative method is chosen as the research approach. The quantitative research uses scientific principles, concrete, empiric, measurable, rational and systematic as research based. Meanwhile, qualitative data is also needed to support the quantitative research to conduct the analysis. The sample is actors who involve in the cultivating process of carrot commodity in Suthomadansih Agropolitan Area. Therefore, some samples are a local farmer, farmer group, actors of carrot home industry, carrot collectors, and carrot retailer, as well as Local Government and NGO's as an enabler of the carrot value chain.

There are two sampling techniques used to conduct the research study, purposive sampling and snowballing sampling by the purposive sampling, the sample of the research study is only people who involved in carrot value chain. They are called as a key person who has a role in cultivating the process of carrot commodity. The second technique is snowball sampling. Snowball sampling is a determining technique of sample that is started with a small number, and then become bigger than before (Sugiyono, 2008). The field interview of the research study will be ended once the researcher believes that the information he obtains is sufficient to conduct the analysis.

In regard to the title of this research, value chain analysis is used to gain data information data information from the field. Based on onion research done by FBC in Nepal (2008), there are five stages of conducting value chain analysis, as follow: 
1. Identify the sequencing activity of carrot cultivating process;

2. Compose the value chain map based on the result of the first stage;

3. Analysis of carrot value added;

4. Defining the function and actors in the value chain map;

5. Defining the roles of enablers.

The second analysis is aimed to identify how the implementation of the agropolitan program in Suthomadansih supports the value chain of carrot as the leading commodity. The description analysis is used to conduct the analysis. According to Iqbal \& Iwan (2009), there are three variables that should be analyzed; the development of supporting infrastructure, agribusiness system, and development of human resource. Matrix comparison is chosen to identify the contribution of the agropolitan program to value chain of carrot. The table 1 describes how to conduct the matrix comparison of implementation of the agropolitan program.

Table 1. Performance of the Implementation of the Agropolitan Program in Suthomadansih

\begin{tabular}{cllll}
\hline No & \multicolumn{1}{c}{ Variables } & \multicolumn{1}{c}{ Expectation } & \multicolumn{1}{c}{ Reality } & $\begin{array}{c}\text { Contribution to value } \\
\text { chain of carrot }\end{array}$ \\
\hline 1 & $\begin{array}{l}\text { The development of } \\
\text { supporting infrastructure }\end{array}$ & $\begin{array}{l}\text { The target of the } \\
\text { program in early of } \\
\text { the implementation } \\
\text { of agropolitan } \\
\text { program }\end{array}$ & $\begin{array}{l}\text { The achievement } \\
\text { of variable } \\
\text { recently }\end{array}$ & $\begin{array}{l}\text { How the variable gives } \\
\text { contribution in the } \\
\text { development of carrot } \\
\text { value chain }\end{array}$ \\
$\begin{array}{l}\text { Development of human } \\
\text { resource }\end{array}$ & & & \\
\hline
\end{tabular}

\section{Overview of Suthomadansih Agropolitan Area}

Suthomadansih as agropolitan area of Karanganyar Regency consists of five districts. They are Tawangmangu District, Karangpandan District, Jenawi District, Ngargoyoso District, and Matesih District (see Figure 1).

Agropolitan program had been implemented in Suthomadansih Agropolitan Area since 2007 to 2009. Department of Agriculture of Karanganyar Regency was the government institution that conducted the program. As a multi-sectoral program, Local Planning Board of Karanganyar Regency and Department of Industry and Commerce of Karanganyar Regency also involved in this program.

As a program based on the development from below concept, agropolitan program should be initiated by the local government, in this case, Government of Karanganyar Regency. Instead of Local Government, the initiative was brought by Farmer Group as named Taman Sari from Tawangmangu District in 2006. Then, in that year, Kimpraswil (Settlement and Regional Infrastructure Board) of Central Java Province surveyed Tawangamangu District with an assumption that the district has potential in vegetable and fruit commodity. In the following year, at 2007, Kimpraswil of Central Java Province started the establishment of Agribusiness Sub Terminal at Tawangmangu District. The construction funding came from Kimpraswil of Central Java Province while the site was provided by Local Government. 


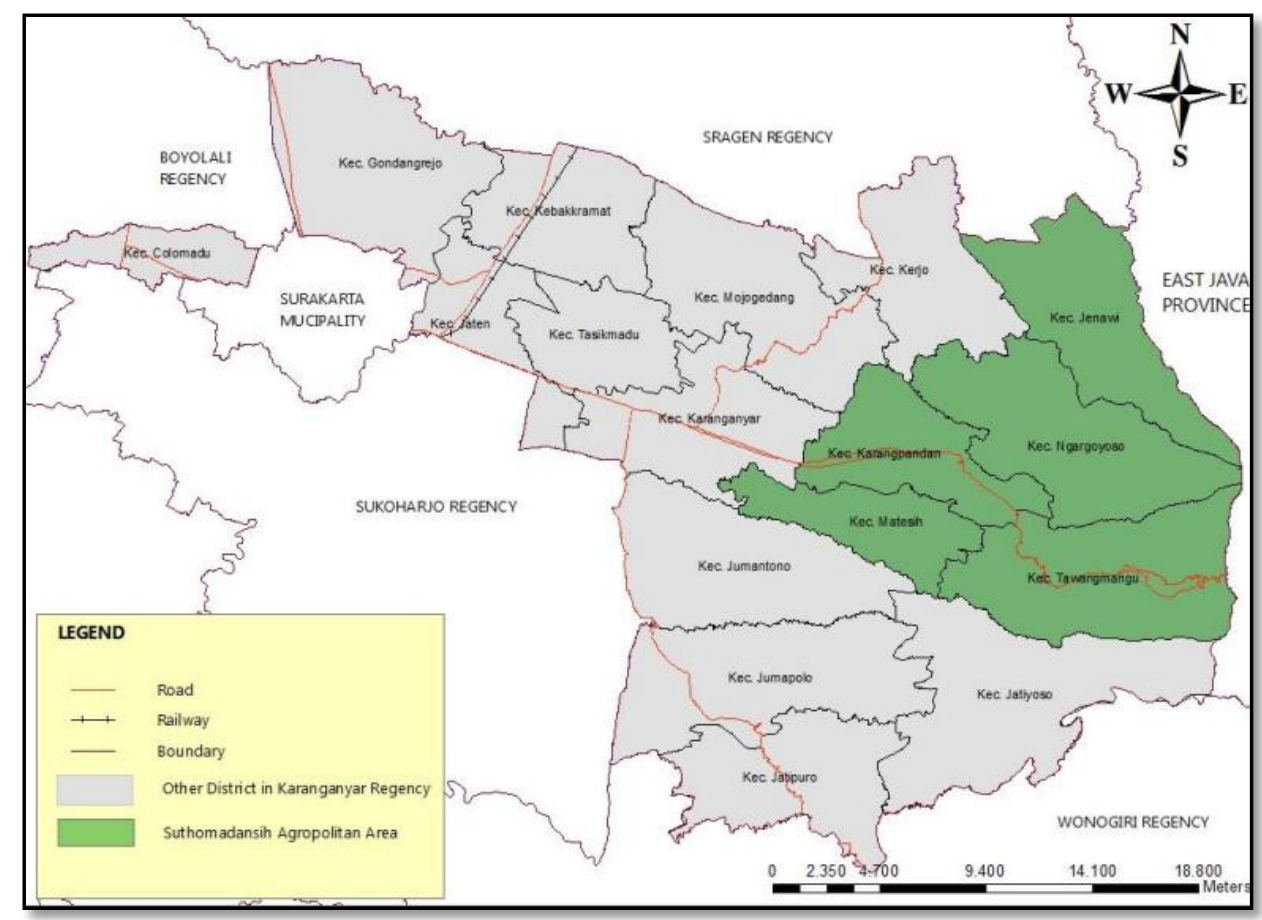

Source: Local Planning Board of Karanganyar Regency, 2012

Figure 1. Map of Suthomadansih Agropolitan Area

\section{Analysis}

There are two analyses explain in this section. The first analysis is about value chain analysis of carrot commodity. By conducting this analysis, the sequencing process of carrot cultivating in Suthomadansih Agropolitan Area, from on-farm (upstream) to off-farm (downstream) will be depicted. The second analysis will investigate how the implementation of the agropolitan program in Suthomadansih Agropolitan Area supports the value chain of carrot.

\section{Value Chain Analysis of Carrot}

There are five stages of conducting a value chain analysis of carrot commodity (FBC, 2008). The first is identifying the sequencing activity of carrot cultivating process. Second, compose the value chain map based on the result of the first stage. Third, analyze the value added of carrot commodity. Fourth, define the actors and the function in the value chain map. Fifth, define the roles of each enabler.

1. Identifying the Sequences Activity of Carrot Cultivating Process

The carrot cultivating process in Suthomadansih Agropolitan Area is started from the on-farm activity (upstream) to off-farm activity (downstream). There are two activities recognized as the derivative product of carrot: carrot seed production (Vitmaka) and instant carrot home industry (Worta). The seeding process (Vitmaka) includes in the on-farm activity. Meanwhile, the home industry of instant carrot (Worta) is defined as part of the off-farm activity. These two derivative products are produced by Tawangmangu's local farmers in Blumbang Village (for Worta Home Industry) and Pancot Village (Vitmaka). 
2. Composing the Value Chain Map of Carrot

The result from the first stage is used to compose the value chain map of carrot. The value chain map of carrot will depict three characteristics: the network structure, the value added, and the governance structure as shown in Figure 2. The network structure shows the vertical and the horizontal dimensions of the carrot value chain map. The vertical dimension is the carrot value chain map itself. While the horizontal dimension shows the relationship among actors in the same chain link (among the farmer, among the collector, etc.). The governance structure shows the role (scope) of institutions as enablers in carrot value chain. Meanwhile, the value added will be depicted in separate diagram.

In the horizontal line, the carrot value chain map shows three components: the functions, the actors, and the enablers. The function refers to some activities occur in carrot cultivating process, from on-farm activity to off-farm activity. The actor refers to people who are involved in carrot cultivating process. While the enabler shows some institutions that conduct and give intervention in the sequencing process of carrot cultivating process. The description of carrot value chain map will be shown in the following Table 2. 
64 Value Chains of Carrot Commodity on Suthomadansih Agropolitan Area in Karanganyar Regency

Table 2. The Description of Carrot Value Chain Map

\begin{tabular}{|c|c|c|c|c|c|}
\hline INFORMATION & INPUT & PRODUCTION & COLLECTING & PROCESSING & MARKETING \\
\hline $\begin{array}{l}\text { Product as an } \\
\text { input }\end{array}$ & & $\begin{array}{l}\text { - Seed } \\
\text { - Equipment } \\
\text { - Fertilizer } \\
\text { - Labor }\end{array}$ & Fresh carrot & Fresh carrot & $\begin{array}{l}\text { - Fresh carrot } \\
\text { - Carrot seed } \\
\text { - Instant carrot }\end{array}$ \\
\hline $\begin{array}{l}\text { Product as an } \\
\text { output }\end{array}$ & $\begin{array}{l}\text { - Seed } \\
\text { - Equipment } \\
\text { - Fertilizer }\end{array}$ & $\begin{array}{l}\text { - Fresh carrot } \\
\text { - Carrot seed }\end{array}$ & Fresh carrot & $\begin{array}{l}\text { - The mix of fresh carrot } \\
\text { - Instant carrot }\end{array}$ & $\begin{array}{l}\text { - Fresh carrot } \\
\text { - Vitmaka (carrot seed) } \\
\text { - Worta (instant carrot) }\end{array}$ \\
\hline $\begin{array}{l}\text { The number of } \\
\text { involved people }\end{array}$ & & $\begin{array}{l}\text { - Based on the data of } \\
\text { Karanganyar in figure } 2009 \text {, } \\
\text { the estimation of carrot } \\
\text { farmer in Suthomadansih is } \\
\text { around14,764 people } \\
\text { (except Matesih District, } \\
\text { there is no carrot farmer). } \\
\text { - Mostly, carrot farmer in } \\
\text { Suthomadansih has an } \\
\text { ability to produce carrot } \\
\text { seed. But only carrot } \\
\text { farmers in Tawangmangu } \\
\text { District who concern in the } \\
\text { development of carrot seed } \\
\text { (Vitmaka). There are } 12,024 \\
\text { carrot farmers in } \\
\text { Tawangmangu District. }\end{array}$ & $\begin{array}{l}\text { The local collector in } \\
\text { Suthomadansih is usually } \\
\text { a member of farmer group. } \\
\text { There are } 25 \text { farmers in } \\
\text { farmer group, where the } 2 \\
\text { of them are local } \\
\text { collectors }(8 \%) \text {. If the } \\
\text { estimation of the local } \\
\text { collector is } 8 \% \text { of the } \\
\text { number of carrot farmer, } \\
\text { the number of the local } \\
\text { collector in } \\
\text { Suthomadansih is } 1,181 \\
\text { people. }\end{array}$ & $\begin{array}{l}\text { - Based on the data of } \\
\text { Karanganyar in figure } \\
2009 \text {, the estimation of a } \\
\text { trader in Suthomadansih is } \\
\text { around } 1,366 \text { people. The } \\
\text { actor that conducts the } \\
\text { mixing process of carrot is } \\
\text { the only trader. The } \\
\text { retailer does not do the } \\
\text { mixing process. } \\
\text { - The production of instant } \\
\text { carrot is only conducted by } \\
\text { farmer group in } \\
\text { Tawangmangu District } \\
\text { (Mekar Sari). There are } 15 \\
\text { farmers as the member of } \\
\text { farmer group. }\end{array}$ & $\begin{array}{l}\text { - Based on the data of } \\
\text { Karanganyar in figure } \\
\text { 2009, the estimation of } \\
\text { trader and retailer in } \\
\text { Suthomadansih is around } \\
4,098 \text { people, where the } \\
\text { retailer is about } 2,732 \\
\text { people. } \\
\text { - Some local farmers sell } \\
\text { the carrot by themselves, } \\
\text { but only several farmers. } \\
\text { The estimation is about } \\
5 \% \text { ( } 738 \text { ). } \\
\text { - The } 15 \text { members of } \\
\text { Mekar Sari's farmer } \\
\text { group have roles as } \\
\text { retailers to sell instant } \\
\text { carrot (Worta). }\end{array}$ \\
\hline Program & & $\begin{array}{l}\text { - Local Government of } \\
\text { Karanganyar Regency } \\
\text { through Department of } \\
\text { Agriculture provides } \\
\text { funding for a local farmer. } \\
\text { The program is PUAP } \\
\text { (Pengembangan Usaha } \\
\text { Agribisnis Pedesaan). This }\end{array}$ & & $\begin{array}{l}\text { - In 2007, Local Planning } \\
\text { Board of Karanganyar } \\
\text { Regency initiated cluster } \\
\text { program to accommodate } \\
\text { farmer group in Blumbang } \\
\text { village. This farmer group } \\
\text { (Mekar Sari) has the } \\
\text { ability to produce instant }\end{array}$ & $\begin{array}{l}\text { - Local Planning Board of } \\
\text { Karanganyar Regency } \\
\text { has a program named } \\
\text { "Channeling Business" } \\
\text { to support a local farmer } \\
\text { in to sell a carrot. During } \\
\text { the implementation of } \\
\text { channeling business }\end{array}$ \\
\hline
\end{tabular}




\begin{tabular}{|c|c|c|c|c|c|}
\hline INFORMATION & INPUT & PRODUCTION & COLLECTING & PROCESSING & MARKETING \\
\hline & & $\begin{array}{l}\text { program is part of PNPM } \\
\text { Mandiri Program. Although } \\
\text { PUAP is not part of the } \\
\text { agropolitan program, PUAP } \\
\text { has been supporting the } \\
\text { implementation of the } \\
\text { agropolitan program until } \\
\text { now. PUAP provides } 100 \\
\text { million for farmer group in } \\
\text { sub-district level } \\
\text { (Gapoktan). Then Gapoktan } \\
\text { will manage the funding. } \\
\text { - Department of Agriculture } \\
\text { has supported supports the } \\
\text { development of carrot seed } \\
\text { since 2007. Actually, there } \\
\text { is no name label for carrot } \\
\text { seed in Karanganyar } \\
\text { Regency before the } \\
\text { implementation of the } \\
\text { agropolitan program. By } \\
\text { starting the agropolitan } \\
\text { program, carrot seed in } \\
\text { Karanganyar Regency, } \\
\text { especially in Suthomadansih } \\
\text { has been named as Vitmaka. } \\
\text { The label is aimed to } \\
\text { enhance the marketability of } \\
\text { carrot seed in } \\
\text { Suthomadansih. The } \\
\text { research and development } \\
\text { process of Vitmaka has been } \\
\text { conducting until now. Local } \\
\text { Government and farmer are } \\
\text { still waiting for approval of }\end{array}$ & & $\begin{array}{l}\text { carrot. The skill obtained } \\
\text { from NGO (Yayasan Duta } \\
\text { Alam) that had given } \\
\text { mentoring since } 2002 \text { to } \\
2007 . \\
\text { - Worta Cluster obtains } \\
\text { wrapping machine from } \\
\text { Ministry of Industry and } \\
\text { Commerce in } 2013 \\
\text { through the Department of } \\
\text { Industry and Commerce of } \\
\text { Karanganyar Regency. }\end{array}$ & $\begin{array}{l}\text { program, farmer groups } \\
\text { are invited to attend } \\
\text { seminar, exhibition, and } \\
\text { auction related to carrot } \\
\text { marketing. Through this } \\
\text { program, local farmers } \\
\text { obtain new market } \\
\text { network for a carrot. In } \\
\text { addition, they also obtain } \\
\text { new knowledge in the } \\
\text { production process of } \\
\text { carrot. } \\
\text { - Kimpraswil of Java } \\
\text { Province and Local } \\
\text { Government of } \\
\text { Karanganyar Regency } \\
\text { established agribusiness } \\
\text { sub-terminal in four } \\
\text { districts in } \\
\text { Suthomadansih: } \\
\text { Tawangmangu District, } \\
\text { Karangpandan, } \\
\text { Ngargoyoso, and Jenawi } \\
\text { District. The agribusiness } \\
\text { sub-terminal is } \\
\text { functioned as a meeting } \\
\text { point between farmer and } \\
\text { collector to do the } \\
\text { transaction. } \\
\text { - Department of } \\
\text { Agriculture in } 2005 \\
\text { initiated "Pasar Jumat" } \\
\text { as a special market for } \\
\text { the farmer to sell their } \\
\text { farming products. }\end{array}$ \\
\hline
\end{tabular}


66 Value Chains of Carrot Commodity on Suthomadansih Agropolitan Area in Karanganyar Regency

\begin{tabular}{|c|c|c|c|c|c|}
\hline INFORMATION & INPUT & PRODUCTION & COLLECTING & PROCESSING & MARKETING \\
\hline Problems & $\begin{array}{l}\text { - Chemical fertilizer } \\
\text { is supplied from } \\
\text { other regencies. } \\
\text { - The price level of } \\
\text { chemical fertilizer } \\
\text { tends to increase. }\end{array}$ & $\begin{array}{l}\text { seed certification from } \\
\text { Ministry of Agriculture. } \\
\text { Sebelas Maret University is } \\
\text { also involved in the } \\
\text { development process of } \\
\text { Vitmaka. } \\
\text { - Farming road improvement } \\
\text { is a program to improve the } \\
\text { quality of the farming road. } \\
\text { This program has been run } \\
\text { during the implementation } \\
\text { of the agropolitan program. } \\
\text { - PUAP program is only } \\
\text { provided for Gapoktan that } \\
\text { has good track record in } \\
\text { fund managing. } \\
\text { - The certification process of } \\
\text { Vitmaka has been taking a } \\
\text { lot of time so that Vitmaka } \\
\text { has not been sold yet to } \\
\text { other regencies. } \\
\text { - Local Government does not } \\
\text { have sufficient budget to } \\
\text { improve all farming roads in } \\
\text { the whole of Suthomadansih } \\
\text { Area. In addition, the } \\
\text { program is also stopped in } \\
\text { 2009. }\end{array}$ & & $\begin{array}{l}\text { - There is a limitation in the } \\
\text { production process of } \\
\text { instant carrot. They are } \\
\text { still using manual way to } \\
\text { produce instant carrot so } \\
\text { that the level production is } \\
\text { only } 50 \mathrm{~kg} / \text { month. } \\
\text { - Conducting the Worta } \\
\text { home industry is not the } \\
\text { priority choice of worta's } \\
\text { member. Farming is the } \\
\text { first choice so that there is } \\
\text { no rapid progress in the } \\
\text { development of Worta } \\
\text { home industry. }\end{array}$ & $\begin{array}{l}\text { - Local farmers tend to sell } \\
\text { carrot to a local collector } \\
\text { rather than selling it by } \\
\text { themselves so that they } \\
\text { can get money more } \\
\text { quickly. } \\
\text { - Pasar Jumat as an } \\
\text { alternative market for } \\
\text { agriculture product now } \\
\text { turns into a market that } \\
\text { sells daily needs. } \\
\text { - Local farmers are still } \\
\text { producing Vitmaka to } \\
\text { fulfill their needs. They } \\
\text { do not consider yet to } \\
\text { produce in large scale so } \\
\text { they could sell the carrot } \\
\text { seed. } \\
\text { - The construction of } \\
\text { Agribusiness sub- } \\
\text { terminal is not in line } \\
\text { with what the local } \\
\text { farmer needs. Local }\end{array}$ \\
\hline
\end{tabular}




\begin{tabular}{|c|c|c|c|c|c|}
\hline INFORMATION & INPUT & PRODUCTION & COLLECTING & PROCESSING & MARKETING \\
\hline & & & & & $\begin{array}{l}\text { farmer as a user of } \\
\text { agribusiness sub-terminal } \\
\text { was not involved in its } \\
\text { construction. Hence, only } \\
\text { two agribusinesses sub- } \\
\text { terminal in } \\
\text { Tawangmangu and } \\
\text { Ngargoyoso District that } \\
\text { are still run/operated } \\
\text { recently. } \\
\text { - Due to the location of } \\
\text { agribusiness sub- } \\
\text { terminal, most farmers } \\
\text { sell their carrot directly } \\
\text { to a local collector in the } \\
\text { field. }\end{array}$ \\
\hline Opportunities & $\begin{array}{l}\text { - Mostly, local } \\
\text { farmers in } \\
\text { Suthomadansih are } \\
\text { also a breeder. } \\
\text { They utilize the } \\
\text { waste as organic } \\
\text { fertilizer. } \\
\text { - Some Gapoktan in } \\
\text { Tawangmangu } \\
\text { District has } \\
\text { initiated to start } \\
\text { organic farming. } \\
\text { Therefore, a local } \\
\text { farmer can reduce } \\
\text { the dependence on } \\
\text { chemical fertilizer. }\end{array}$ & $\begin{array}{l}\text { - Local Government can } \\
\text { initiate the cooperation with } \\
\text { NGOs to conduct some } \\
\text { agriculture programs in } \\
\text { Suthomadansih, especially } \\
\text { in empowering program. } \\
\text { Worta can be the reference. } \\
\text { - Speed up the process of } \\
\text { certification of Vitmaka. }\end{array}$ & & $\begin{array}{l}\text { - Inviting the private sector } \\
\text { to join in the development } \\
\text { of Worta. The professional } \\
\text { management may be more } \\
\text { appropriate to manage } \\
\text { Worta as a derivative } \\
\text { product of carrot. } \\
\text { - There are other derivative } \\
\text { products from carrot that } \\
\text { can be an alternative way } \\
\text { to increase the income of } \\
\text { farmers, such as carrot } \\
\text { juice, carrot crispy, and } \\
\text { carrot noodle. }\end{array}$ & $\begin{array}{l}\text { - There is an available } \\
\text { market for carrot seed } \\
\text { either in inside or outside } \\
\text { of Suthomadansih, such } \\
\text { as Dieng District in } \\
\text { Wonosobo Regency. } \\
\text { - Encouraging the local } \\
\text { farmer to produce more } \\
\text { carrot seed (Vitmaka). }\end{array}$ \\
\hline
\end{tabular}


68 Value Chains of Carrot Commodity on Suthomadansih Agropolitan Area in Karanganyar Regency

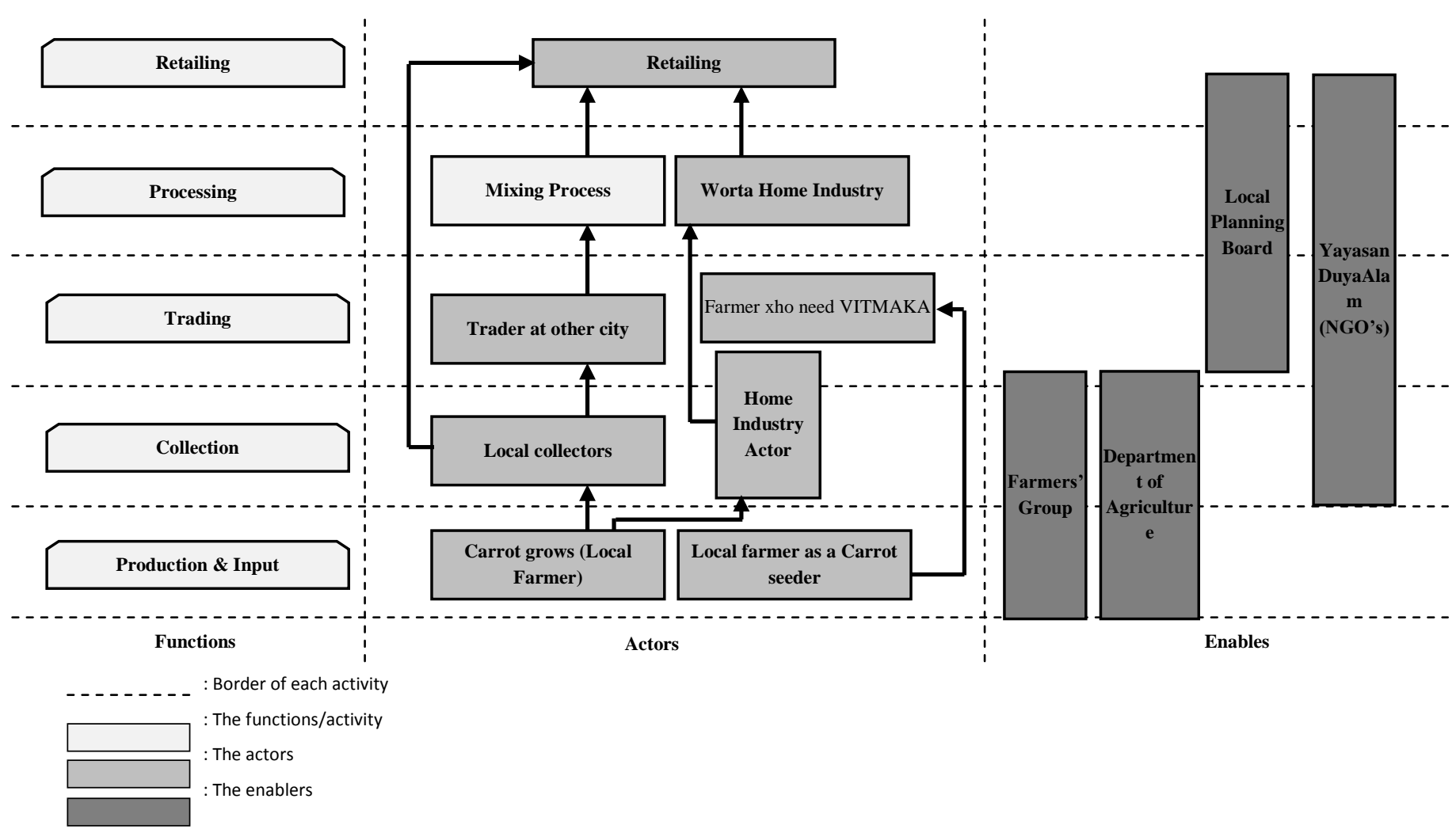

Figure 2. Carrot Value Chain Map

3. Carrot Value Added

Based on the carrot value chain map in Figure 3, the whole value added the process of carrot commodity in Suthomadansih Agropolitan Area will be depicted in the diagram below. The detailed description about carrot value added will be explained in Table 3. Meanwhile, for deep analysis of fresh carrot and its derivative product will be presented in the following analysis. 


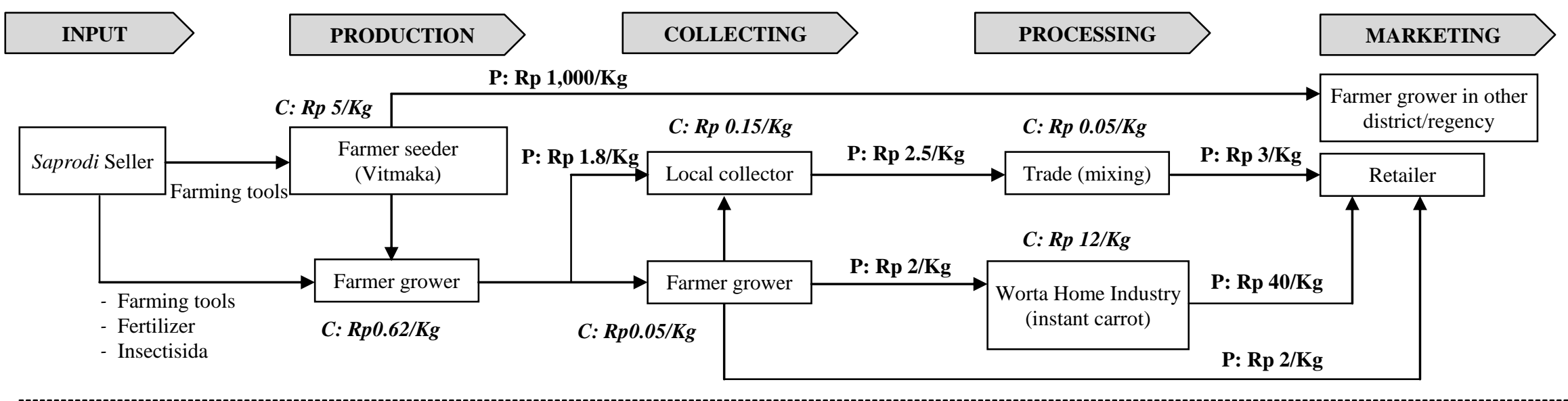

C: cost (in a thousand)

$P$ : price (in a thousand)

Figure 3. Carrot Value Added

Table 3. Detailed Calculation of Carrot Value Added

\begin{tabular}{|c|c|c|c|c|c|}
\hline INFORMATION & INPUT & PRODUCTION & COLLECTING & PROCESSING & MARKETING \\
\hline \multirow{4}{*}{$\begin{array}{l}\text { Detailed } \\
\text { calculation for } \\
\text { fresh carrot }\end{array}$} & & Assumptions & & & \\
\hline & & $\begin{array}{l}\text { Assumptions: the harvesting } \\
\text { process is conducted by carrot } \\
\text { farmer. }\end{array}$ & $\begin{array}{l}\text { Assumptions: local carrot is } \\
\text { only sold to a local trader. }\end{array}$ & & \\
\hline & & Cost & & & \\
\hline & & $\begin{array}{l}\text { Carrot farmers spent ten million } \\
\text { rupiahs/ha to grow a carrot. Then } \\
\text { they could harvest about } 15 \text { ton } \\
\text { fresh carrot. Therefore, carrot cost } \\
\text { per kg is Rp } 670 \text {. } \\
\text { Here the detailed cost: } \\
\text { - Seed: Rp } 80 \\
\text { - Saprodi: Rp } 370\end{array}$ & $\begin{array}{l}\text { Local collectors spent Rp } \\
\text { 1,950/kg for a carrot. } \\
\text { Here the cost detail: } \\
\text { - Fresh carrot: Rp } 1,800 / \mathrm{kg} \\
\text { - Washing cost: } \mathrm{Rp} 100 / \mathrm{kg} \text {. } \\
\text { Transportation: Rp 50/kg. }\end{array}$ & $\begin{array}{l}\text { Local traders spent } \mathrm{Rp} \\
\text { 2,550/kg for a carrot. } \\
\text { Here the cost detail: } \\
\text { Fresh carrot: } \mathrm{Rp} 2,500 / \mathrm{kg}\end{array}$ & $\begin{array}{l}\text { Local retailers spent } \mathrm{Rp} \\
3,100 / \mathrm{kg} \text { for a fresh } \\
\text { carrot. } \\
\text { Here the cost detail: } \\
\text { - Fresh carrot: } \mathrm{Rp} \\
\text { 3,000/kg } \\
\text { - Transportation: Rp } \\
\text { 100/kg }\end{array}$ \\
\hline
\end{tabular}


70 Value Chains of Carrot Commodity on Suthomadansih Agropolitan Area in Karanganyar Regency

\begin{tabular}{|c|c|c|c|c|c|}
\hline INFORMATION & INPUT & PRODUCTION & COLLECTING & PROCESSING & MARKETING \\
\hline \multirow{11}{*}{$\begin{array}{l}\text { Detailed } \\
\text { calculation for } \\
\text { carrot seed } \\
\text { (Vitmaka) }\end{array}$} & & $\begin{array}{l}\text { - Field preparation: Rp } 170 \\
\text { - Harvesting: Rp } 50\end{array}$ & & & \\
\hline & & Revenue & & & \\
\hline & & $\begin{array}{l}\text { Carrot farmers sell } 1 \mathrm{~kg} \text { carrot to a } \\
\text { local collector for } \mathrm{Rp} 1,800 \text {. }\end{array}$ & $\begin{array}{l}\text { Local collectors sell } 1 \mathrm{~kg} \\
\text { carrot to a local trader for } \mathrm{Rp} \\
2,500 \text {. }\end{array}$ & $\begin{array}{l}\text { Local traders sell } 1 \mathrm{~kg} \\
\text { fresh carrot to a local } \\
\text { retailer for } \mathrm{Rp} 3,000 .\end{array}$ & $\begin{array}{l}\text { Local retailers sell } 1 \mathrm{~kg} \\
\text { fresh carrot to the } \\
\text { consumer for } \mathrm{Rp} 3,500 \text {. }\end{array}$ \\
\hline & & Profit Margin & & & \\
\hline & & $\begin{array}{l}\text { Carrot farmer obtains profit } \\
\text { Rp1,130/kg. }\end{array}$ & $\begin{array}{l}\text { Local collector obtains profit } \\
\text { Rp 550/kg. }\end{array}$ & $\begin{array}{l}\text { Local trader obtains profit } \\
\text { Rp } 450 / \mathrm{kg} \text {. }\end{array}$ & $\begin{array}{l}\text { Local retailer obtains } \\
\text { profit } \mathrm{Rp} 400 / \mathrm{kg} \text {. }\end{array}$ \\
\hline & & Total value per year & & & \\
\hline & & $\begin{array}{l}\text { Total production carrot per year is } \\
\text { about } 114,003 \mathrm{kw} \text { (BPS, 2011). }\end{array}$ & & & $\begin{array}{l}\text { Total value of fresh } \\
\text { carrot per year is about } \\
\operatorname{Rp} 399,010,500\end{array}$ \\
\hline & & Assumptions & & & \\
\hline & & $\begin{array}{l}\text { Assumption: } \\
\text { - Seeder uses fresh carrot grade } \mathrm{A}^{2} \\
\text { as input. } \\
\text { - Five kilograms carrot grade A } \\
\text { could produce } 0.25 \mathrm{~kg} \text { Vitmaka. } \\
\text { - The price of carrot grade A is Rp } \\
2,000 / \mathrm{kg} \text {. } \\
\text { - Operational cost }{ }^{3} \text { to process } 1 \mathrm{~kg} \\
\text { carrot } \\
\text { - Grade A is Rp } 10,000\end{array}$ & & & \\
\hline & & Cost & & & \\
\hline & & $\begin{array}{l}\text { In order to produce } 1 \mathrm{~kg} \mathrm{Vitmaka}{ }^{4} \text {, } \\
\text { seeder spent Rp } 240,000 \text {. Here the } \\
\text { detailed cost: } \\
\text { - 20kg carrot grade A: Rp 40,000 }\end{array}$ & & & \\
\hline
\end{tabular}

\footnotetext{
${ }^{2}$ Farmers in Suthomadansih Agropolitan Area typically use grade A carrot in the seeding process. It is aimed to obtain high quality seeds. The difference in the carrot grade lies in the physical size, which is big for grade A (> 250gr), medium for grade B (100gr-200gr), and small for grade C $(<100 \mathrm{~g})$. In the seeding process, one kilogram of carrots grade A will produce \pm 50 grams of carrot seeds (Vitmaka). Carrot grade A can be seen in Annex 2 figure 12.

3 Operational cost for plastic, seeding house, seeding media (soil), fertilizer, and human resources.

${ }^{4}$ Farmer seeder needs about 4-6 months to produce carrot seed (Vitmaka).
} 


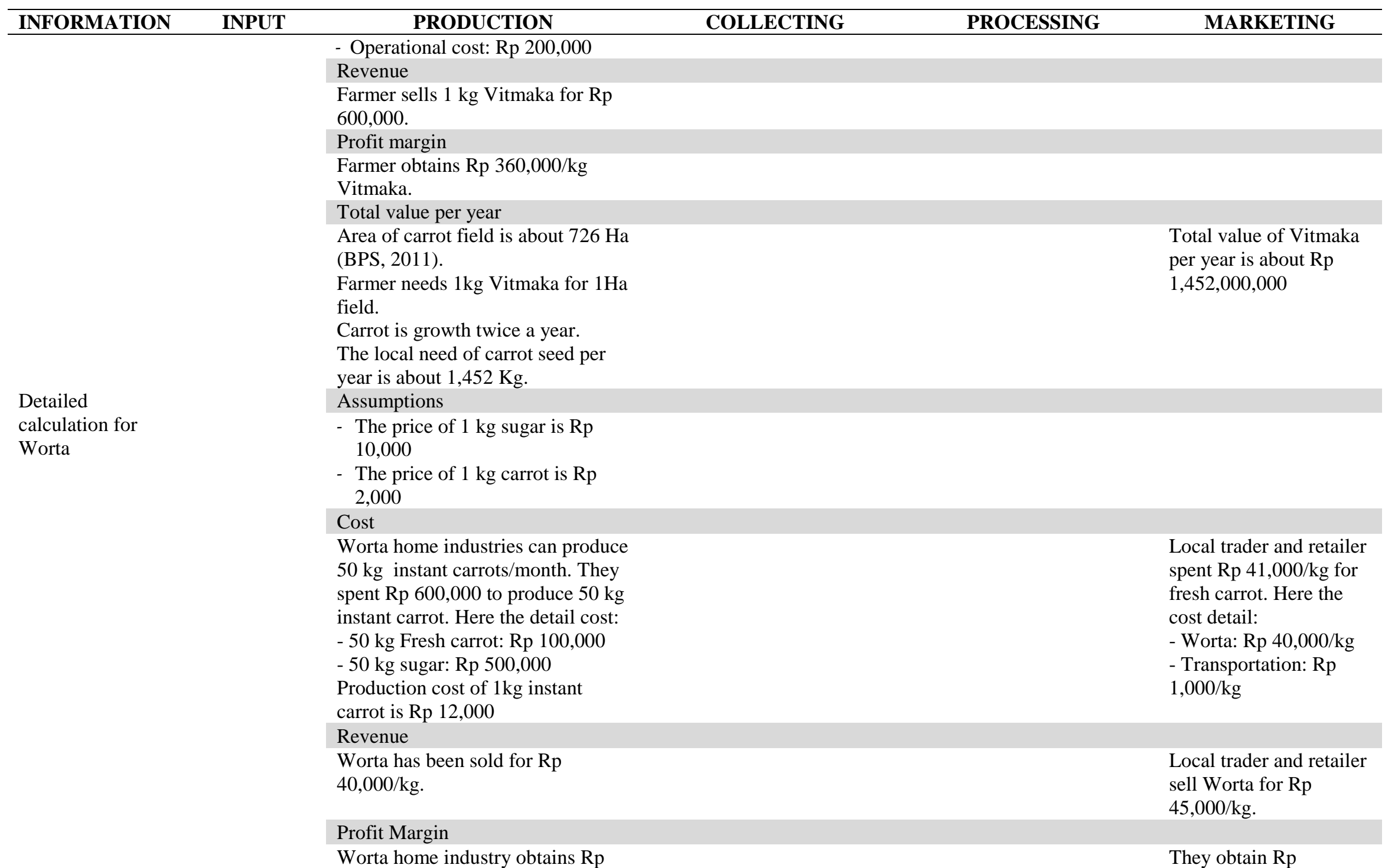


72 Value Chains of Carrot Commodity on Suthomadansih Agropolitan Area in Karanganyar Regency

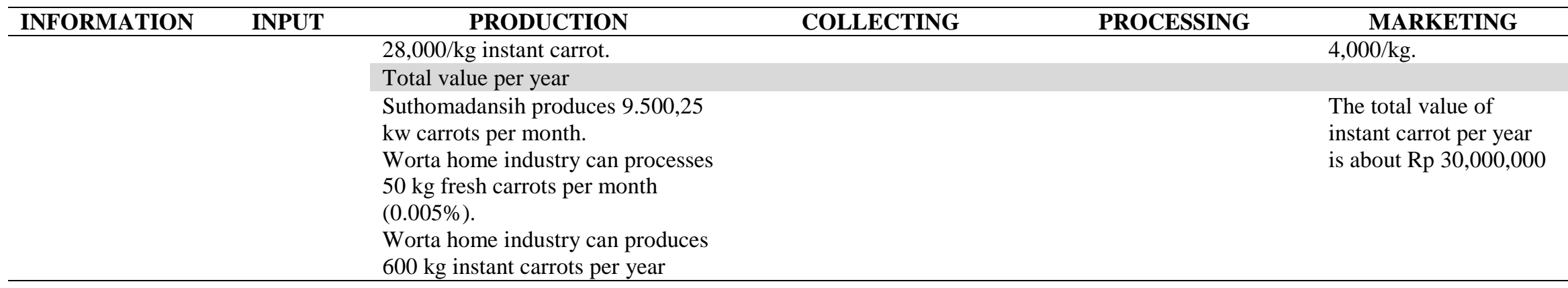


4. Defining the Function and Actors in the Value Chain Map

- Carrot Farmer

Carrot farmer in Suthomadansih Agropolitan Area has two functions: as carrot grower and as carrot seeder. Mostly, carrot farmers cultivate their own farmland, while the rest rent the farmland from other farmers who have large farmland. Rental price is calculated based on the total land area used per year. For some carrot farmers, farmland is not the only media to plant the carrot. They also utilize the home yard to cultivate the carrot. Carrot farmers also utilize the home yard as a seeding laboratory.

Besides as carrot growers and seeder, some carrot farmers, particularly in Blumbang Village, Tawangmangu District also have the roles as home industry actors. They are members of the Mekarsari Farmer Group, producing instant carrot (Worta).

- Carrot Home Industry Actors

As mentioned above, some carrot farmers in Blumbang Village, Tawangmangu have roles as home industry actors. They produce instant carrot namely Worta. Worta is not only as the product name but also as the name of carrot home industry's cluster. Worta Cluster was established by Local Planning Board of Karanganyar Regency, in line with the implementation of the agropolitan program in 2007. For the member of Mekarsari Farmer Group, Worta Home Industry also gives a chance to get a higher carrot price than the market price. Worta Home Industry usually buys carrot from the members. It sets the fixed price, i.e. Rp $2.000 / \mathrm{Kg}$ for the carrot bought from the members. When the market price is higher than the fixed price, Worta Home Industry will buy in accordance with the market price. When the market price is lower than the fixed price, Worta Home Industry will buy at the fixed price.

- Local Collectors

Local collectors are directly involved in buying carrots from local farmers in Suthomadansih Agropolitan Area. They are also selling carrots to traders or retailers at the local market in Karanganyar Regency and outside Karanganyar Regency, such as Sragen Regency, Boyolali Regency, Surakarta Municipality, Sukoharjo Regency, Sleman Regency, and Klaten Regency.

- Traders

Traders often buy carrot from the local collectors and directly from the carrot farmers in the vicinity. For traders from other cities, they often get supplies from the local collectors. In running their business, some traders mix carrots from Suthomadansih with carrots from other regencies. Traders also supply retailers in traditional markets. Therefore, traders combine the functions of collecting and selling their carrots in the market.

- Retailers

There are numerous carrot retailers in Suthomadansih Agropolitan Area who caters to the household consumers. These retailers also sell other vegetables and other items. Retailers on motorcycle and bicycle also sell carrot and another vegetable door to door. In addition, retailers also sell carrot in traditional markets surrounding the Suthomadansih Agropolitan Area.

5. Defining the Roles of Enablers

Local Government and Non-Governmental Organizations play important roles in moving the carrot commodity along the value chain. The functions and roles of the enablers, as depicted in the Carrot Value Chain Map (Figure 2) are described as follows (Table 4): 
Table 4. Roles of Enablers

\begin{tabular}{|c|c|}
\hline Enablers & Role \\
\hline Department of Agriculture & $\begin{array}{l}\text { - Implementing the agropolitan program. } \\
\text { - Providing the training and mentoring related to farm } \\
\text { cultivation. } \\
\text { - Implementing the PUAP program as a funding program for } \\
\text { farmer through Gapoktan (The United of Farmer Group in } \\
\text { village level). } \\
\text { - Initiating the "Pasar Jumat" as a special market for the farmer } \\
\text { to sell their farming product. }\end{array}$ \\
\hline $\begin{array}{l}\text { Department of Industry and } \\
\text { Commerce }\end{array}$ & $\begin{array}{l}\text { - Providing the training of post-harvesting process, i.e.: } \\
\text { packaging, processing product. } \\
\text { - Providing the network market for carrot trading. } \\
\text { - Providing wrapping machine for Worta home industry. }\end{array}$ \\
\hline Local Planning Board & $\begin{array}{l}\text { - Establishing the agropolitan network among the agropolitan } \\
\text { areas in Java Island, particularly in Central Java Province. } \\
\text { - Establishing the Worta Cluster to promote the Carrot Home } \\
\text { Industry in Suthomadansih Agropolitan Area. } \\
\text { - Providing equipment for producing instant carrot. }\end{array}$ \\
\hline Yayasan Duta Alam (NGO) & $\begin{array}{l}\text { - Providing training and assistance to farmer groups in Blumbang } \\
\text { Village for instant carrot production. } \\
\text { - Providing equipment for producing instant carrot. }\end{array}$ \\
\hline $\begin{array}{l}\text { Sebelas Maret University } \\
\text { Gapoktan (the united of farmer } \\
\text { group in village level) }\end{array}$ & $\begin{array}{l}\text { - As a place where laboratory test of Vitmaka takes place. } \\
\text { - As farmer association to channel funds from PUAP. }\end{array}$ \\
\hline Farmer's Group & $\begin{array}{l}\text { - As a media for farmers to gain knowledge related to cultivating } \\
\text { process. } \\
\text { - Providing information related to farmer commodity prices }\end{array}$ \\
\hline
\end{tabular}

\section{The Findings}

There are some findings based on the value chain analysis of carrot commodity in Suthomadansih Agropolitan Area. The findings are related to program, problem, and opportunity. Furthermore, Table 5 shows the performance of the implementation of the agropolitan program in Suthomadansih.

1. Development program from Local Government has been conducted from upstream to downstream of carrot commodity production. However, some programs failed to support the value chain of carrot so that the improvement of the value chain of carrot could not be optimized. One of the failed programs is agribusiness sub-terminal.

2. There are potential markets for carrot seeds, especially in Dieng District, Wonosobo Regency. However, Vitmaka has not received certification from Ministry of Agriculture yet so that the selling with label Vitmaka could not be done.

3. The biggest profit margin is derived from instant carrot that is about $233 \%$ then followed by farmer seeder (Vitmaka) which is about 150\%. 12,039 people are directly involved and receive the profits of carrot commodity. However, mostly farmers only produce carrot seed for fulfilling their need. Therefore, the number of people who is directly involved and receives the profit margin may decrease.

4. Although Worta has the biggest profit margin, the production level is still low. Thus, Worta has not been one of the alternative ways of getting extra income for the farmers yet. In the other hand, Vitmaka has market potency both inside and outside the area of Karanganyar Regency so that it can serve as alternative income for farmers. 
5. The potential money flowing from carrot commodity per year is about Rp $1,881,010,500$. Vitmaka has the highest potency to lift up the economic condition of

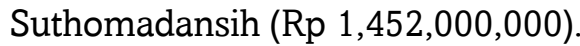

6. The development of agribusiness sub-terminal does not meet the need of local farmer. A local farmer was not involved in the development of agribusiness subterminal.

Table 5. Performance of the Implementation of the Agropolitan Program in Suthomadansih

\begin{tabular}{|c|c|c|c|c|}
\hline No. & Variables & Expectation & Reality & $\begin{array}{c}\text { Contribution to value } \\
\text { chain of carrot }\end{array}$ \\
\hline \multirow[t]{3}{*}{1.} & \multicolumn{4}{|c|}{ The Development of Supporting Infrastructure } \\
\hline & $\begin{array}{l}\text { Agribusiness sub- } \\
\text { terminal }\end{array}$ & $\begin{array}{l}\text { This facility is aimed as } \\
\text { a new meeting point } \\
\text { between farmer and } \\
\text { trader to do the } \\
\text { transaction. Not only } \\
\text { local traders from } \\
\text { Suthomadansih, the sub- } \\
\text { terminal can also be } \\
\text { used by traders from } \\
\text { other regions. } \\
\text { - Tax from agribusiness } \\
\text { sub-terminal will be } \\
\text { used as local income of } \\
\text { Karanganyar Regency. }\end{array}$ & $\begin{array}{l}\text { - Local and provincial } \\
\text { governments built four } \\
\text { terminals, but only two } \\
\text { terminals that are still } \\
\text { functioning. } \\
\text { - Revenue from the } \\
\text { Agribusiness Sub- } \\
\text { terminal currently only } \\
\text { revolves around2.5 } \\
\text { million rupiahs per } \\
\text { month, so it has never } \\
\text { been considered as local } \\
\text { income of Karanganyar } \\
\text { Regency. }\end{array}$ & $\begin{array}{l}\text { - There is carrot } \\
\text { washing machine in } \\
\text { Agribusiness sub- } \\
\text { terminal which is } \\
\text { still functioning, so } \\
\text { the traders or the } \\
\text { collectors can use it. }\end{array}$ \\
\hline & $\begin{array}{l}\text { Farm road } \\
\text { improvement } \\
\text { program }\end{array}$ & $\begin{array}{l}\text { This program is aimed } \\
\text { to improve the } \\
\text { accessibility of local } \\
\text { farmers in } \\
\text { Suthomadansih to their } \\
\text { farmland. }\end{array}$ & $\begin{array}{l}\text { - This program is not } \\
\text { implemented on the } \\
\text { entire agropolitan area. } \\
\text { The program is only } \\
\text { implemented in some } \\
\text { locations with the length } \\
\text { of the road is not further } \\
\text { than a kilometer for each } \\
\text { district. }\end{array}$ & $\begin{array}{l}\text { - This program fosters } \\
\text { the participation of } \\
\text { farmers to participate } \\
\text { in the development/ } \\
\text { improvement of the } \\
\text { farming road. }\end{array}$ \\
\hline \multirow[t]{3}{*}{2.} & \multicolumn{4}{|c|}{ Agribusiness System } \\
\hline & $\begin{array}{l}\text { The existence } \\
\text { of financial } \\
\text { institutions }\end{array}$ & $\begin{array}{l}\text { - To provide loans to } \\
\text { farmers with easy terms. }\end{array}$ & $\begin{array}{l}\text { - There is no financial } \\
\text { institution }\end{array}$ & $\begin{array}{l}\text { - There is no } \\
\text { contribution to value } \\
\text { chain of carrot. }\end{array}$ \\
\hline & $\begin{array}{l}\text { Partnership } \\
\text { building } \\
\text { (channeling } \\
\text { business) }\end{array}$ & $\begin{array}{l}\text { - To develop the network } \\
\text { for expanding the } \\
\text { market area of carrot. }\end{array}$ & $\begin{array}{l}\text { - Local government } \\
\text { invites Farmer Groups } \\
\text { in Suthomadansih to } \\
\text { visit other farmer groups } \\
\text { in outside regions of } \\
\text { Karanganyar Regency. }\end{array}$ & $\begin{array}{l}\text { - A local farmer has a } \\
\text { new network with } \\
\text { other farmer groups. } \\
\text { But it does not give } \\
\text { any influence yet to } \\
\text { the marketing } \\
\text { process. }\end{array}$ \\
\hline \multirow[t]{2}{*}{3.} & \multicolumn{4}{|c|}{ The Development of Human Resource } \\
\hline & $\begin{array}{l}\text { Cluster program } \\
\text { of Worta }\end{array}$ & $\begin{array}{l}\text { - To provide production } \\
\text { tools to produce instant } \\
\text { carrot. } \\
\text { - To promote Worta to } \\
\text { other regencies. }\end{array}$ & $\begin{array}{l}\text { - Worta Cluster has been } \\
\text { established since } 2007 . \\
\text { - Worta Cluster obtains } \\
\text { fund to buy production } \\
\text { tools from Local } \\
\text { Planning Board. } \\
\text { Department of Industry } \\
\text { also gives wrapping } \\
\text { machine to Worta }\end{array}$ & $\begin{array}{l}\text { - Worta Cluster obtains } \\
\text { production tools to } \\
\text { produce instant } \\
\text { carrot. }\end{array}$ \\
\hline
\end{tabular}




\begin{tabular}{|c|c|c|c|c|}
\hline No. & Variables & Expectation & Reality & $\begin{array}{c}\text { Contribution to value } \\
\text { chain of carrot }\end{array}$ \\
\hline & & & $\begin{array}{l}\text { Cluster. } \\
\text { - Worta Cluster still cannot } \\
\text { find an appropriate } \\
\text { market for selling their } \\
\text { instant carrot. }\end{array}$ & \\
\hline & $\begin{array}{l}\text { Empowering } \\
\text { program to } \\
\text { develop local } \\
\text { carrot seeds } \\
\text { (Vitmaka) }\end{array}$ & $\begin{array}{l}\text { - To support farmers in } \\
\text { developing the original } \\
\text { carrot seeds from } \\
\text { Suthomadansih. } \\
\text { - To get the certification of } \\
\text { carrot seeds so that they } \\
\text { can be marketed widely } \\
\text { - To promote Vitmaka to } \\
\text { other regencies. }\end{array}$ & $\begin{array}{l}\text { - The seed certification has } \\
\text { not been obtained yet. } \\
\text { - Vitmaka is only used by } \\
\text { local farmers in } \\
\text { Suthomadansih. }\end{array}$ & $\begin{array}{l}\text { - Vitmaka has not been } \\
\text { sold yet to other } \\
\text { regencies. }\end{array}$ \\
\hline & $\begin{array}{l}\text { Training for } \\
\text { carrot processing }\end{array}$ & $\begin{array}{l}\text { - To encourage local } \\
\text { farmer } \\
\text { - To find new alternatives } \\
\text { - To sell a carrot. }\end{array}$ & $\begin{array}{l}\text { - Due to the market } \\
\text { condition, the farmer is } \\
\text { still unwilling to process } \\
\text { carrot into other } \\
\text { products. }\end{array}$ & $\begin{array}{l}\text { - Local farmer obtains } \\
\text { references how to } \\
\text { process fresh carrot } \\
\text { into other products, } \\
\text { but they still prefer to } \\
\text { sell a fresh carrot. }\end{array}$ \\
\hline & $\begin{array}{l}\text { The agricultural } \\
\text { extension } \\
\text { program }\end{array}$ & $\begin{array}{l}\text { - To increase the quality } \\
\text { and quantity of carrot } \\
\text { commodity. }\end{array}$ & $\begin{array}{l}\text { - In fact, without the } \\
\text { empowering program, a } \\
\text { local farmer can increase } \\
\text { the quality and quantity } \\
\text { of carrot. However, local } \\
\text { farmers can obtain more } \\
\text { knowledge to cultivate } \\
\text { their farming land. }\end{array}$ & $\begin{array}{l}\text { Through this } \\
\text { program, a local } \\
\text { farmer has media to } \\
\text { solve the problem } \\
\text { related to their } \\
\text { farming activity. }\end{array}$ \\
\hline
\end{tabular}

\section{Conclusion}

Based on the value chain of carrot commodity in Suthomadansih, development program from the local government through the agropolitan program has been conducted from upstream to downstream. However, some programs failed to support the value chain of carrot commodity so that the improvement of the value chain of carrot commodity could not be optimized.

The implementation of the agropolitan program is not sustainable because of the lack of the budgets of local governments. The program is only implemented for 3 years (20072009) so that there are no significant effects of the program on the agricultural sector, especially for carrot commodity. The programs that are parts of the agropolitan program are Agribusiness Sub-Terminal, Worta Cluster, Vitmaka, and Farm Road Improvement Program.

\section{References}

Full Bright Consultancy (FBC). (2008). Product chain study onion. Nepal: Full Bright Consultancy (Pvt.) Ltd.

Herr, M. L. (2007). An operational guide to local value chain development. International Labour Organization: Enterprise for Pro-poor Growth (Enter-Growth).

Iqbal, M., \& Anugrah, I. S. (2009). Rancang bangun sinergi kebijakan agropolitan dan pengembangan ekonomi lokal menunjang percepatan pembangunan wilayah. Journal of Analisis Kebijakan Pertanian, 72), 169188. 
Kaplinsky, R., \& Morris, M. (2001). A handbook for value chain research. Retrieved from http://www.prism.uct.ac.za/.

Rustiadi, E., Saefulhaim, S., \& Panuju, D. R. (2009). Perencanaan dan pengembangan wilayah. Jakarta: Cooperating between Crestpent Press and Yayasan Obor.

Sugiyono. (2008). Metode penelitian kuantitatif, kualitatif dan $R \& D$. Bandung: Alfabeta.

Supriatna, A. Sejati, W. K., Hidayat, D., \& Rusastra, I. W. (2005). Kinerja dan perspektif pengembangan model agropolitan berbasis agribisnis di Kabupaten Cianjur Jawa Barat. Retrieved from http://pse.litbang.pertanian.go.id/ind/pdffiles/WP_77_2005.pdf. 
78 Value Chains of Carrot Commodity on Suthomadansih Agropolitan Area in Karanganyar Regency

JURNAL WILAYAH DAN LINGKUNGAN, 3 (1), 59-78 